\title{
Process development for pandemic influenza VLP vaccine production using a baculovirus expression system
}

\author{
Chia-Chun Lai ${ }^{1,2}$, Yu-Chieh Cheng ${ }^{1}$, Pin-Wen Chen ${ }^{1}$, Ting-Hui Lin ${ }^{1,2}$, Tsai-Teng Tzeng ${ }^{1}$, Chia-Chun Lu', \\ Min-Shi Lee ${ }^{1}$ and Alan Yung-Chih $\mathrm{Hu}^{1 *}$
}

\begin{abstract}
Background: Influenza viruses cause hundreds of thousands of respiratory diseases worldwide each year, and vaccination is considered the most effective approach for preventing influenza annual epidemics or pandemics. Since 1950, chicken embryonated eggs have been used as the main method for producing seasonal influenza vaccines. However, this platform has the main drawback of a lack of scale-up flexibility, and thus, egg-based vaccine manufacturers cannot supply sufficient doses within a short period for use for pandemic prevention. As a result, strategies for reducing the manufacturing time and increasing production capacity are urgently needed. Non-virion vaccine methods have been considered an alternative strategy against an influenza pandemic, and the purpose of maintaining an immunogenic capsule structure with infectious properties appears to be met by the virus-like particle (VLP) platform.
\end{abstract}

Results: An influenza H7N9-TW VLP production platform using insect cells, which included the expression of hemagglutinin (HA), NA, and M1 proteins, was established. To scale up H7N9-TW VLP production, several culture conditions were optimized to obtain a higher production yield. A high level of dissolved oxygen (DO) could be critical to H7N9-TW VLP production. If the DO was maintained at a high level, the HA titer obtained in the spinner flask system with ventilation was similar to that obtained in a shake flask. In this study, the HA titer in a 5-L bioreactor with a well-controlled DO level was substantially improved by 128-fold (from $4 \mathrm{HA}$ units (HAU)/50 $\mu \mathrm{L}$ to $512 \mathrm{HAU} / 50 \mu \mathrm{L})$.

Conclusions: In this study, a multigene expression platform and an effective upstream process were developed. Notably, a high H7N9-TW VLP yield was achieved using a two-step production strategy while a high DO level was maintained. The upstream process, which resulted in high VLP titers, could be further used for large-scale influenza VLP vaccine production.

Keywords: Influenza vaccines, Virus-like particle, Dissolved oxygen

\section{Background}

Influenza virus infections often cause human respiratory symptoms and result in public health concerns regarding seasonal and endemic infections and even unpredictable pandemic outbreaks. Currently, the most effective method for preventing influenza infection caused by the influenza virus is vaccination. Most influenza vaccines are manufactured

\footnotetext{
* Correspondence: alanhu@nhri.edu.tw

${ }^{1}$ National Institute of Infectious Diseases and Vaccinology, NHRI, 35 Keyan

Road, Zhunan, Miaoli County 35053, Taiwan

Full list of author information is available at the end of the article
}

using split antigen, inactivated whole-virion, or live attenuated method [1]. Although these vaccines exhibit high efficacy, biosafety concerns regarding the use of highly pathogenic avian influenza (HPAI) during the manufacturing process are an issue, and thus, the development of safer vaccines is needed. Virus-like particles (VLPs) are produced through the self-assembly of essential viral structural proteins expressed in a cell and exhibit morphological and structural features that are similar to those of native viruses. Because VLPs do not contain any infectious genetic materials, these particles are safer than whole-viral vaccines [2] and are thus

(c) The Author(s). 2019 Open Access This article is distributed under the terms of the Creative Commons Attribution 4.0 International License (http://creativecommons.org/licenses/by/4.0/), which permits unrestricted use, distribution, and 
considered a safe vaccine platform [3]. Recent evidence suggests that VLPs constitute a vaccine platform technology with high potential for use for a wide range of infectious viruses [4-6]. VLP vaccines have been produced using different expression systems, including bacterial, yeast, insect, mammalian, and plant systems [7-10]. Strategies to decrease the response time and increase the productivity of vaccines are urgently needed for pandemic preparedness. One of the most promising approaches is the production of VLP-based vaccines using the baculovirus expression vector system (BEVS) [11], which provides a rapid and efficient method to generate multiple recombinant proteins for the formation of VLPs. To date, several established insect cell lines have been shown to be susceptible to baculovirus infection [11-13]. Previous studies [14-16] have shown that a number of factors can influence protein expression, and these include the production media, the level of dissolved oxygen (DO), the virus multiplicity of infection (MOI) and the time point after infection used for harvesting. Notably, these established insect cell lines show variable abilities to amplify baculovirus and express soluble protein. In addition, these previous studies have suggested that different production conditions support the production of varying levels of protein expression $[17,18]$. Therefore, optimal culturing conditions are essential for VLP production.

Over the past 10 years, HPV vaccines based on VLP production techniques using insect cells (Cervarix ${ }^{\circ}$, GSK) have been licensed by the U.S. FDA [19-21]. This vaccine can protect against cervical and anogenital infections and diseases. The development of a vaccine production system using insect cells has attracted the attention of many scientists $[5,6,10,22-24]$. The influenza VLP structure could be self-assembled by different hemagglutinin (HA), NA, and M1 proteins, which have been shown to antagonize the threat of new influenza pandemics and increase the flexibility of their manufacturing $[7,22,25,26]$. The BEVS was used to develop an influenza VLP vaccine by Novavax, Inc. [27-29] and a recombination influenza subunit protein by the Protein Sciences Corporation [30, 31] to improve the response time for influenza pandemic preparedness, and these studies have demonstrated that insect cell culture-based manufacturing has been accepted in the influenza vaccine industry.

A recent H7N9 influenza virus outbreak occurred in China, and recent cases have also been reported in Taiwan [32, 33]. Hence, in Taiwan, the H7N9 influenza virus poses health risks and might lead to an outbreak. In this study, we developed a H7N9-TW VLP production method using BEVS and used this method to generate a multigene expression vector for coexpressing the essential components ( $\mathrm{H} 7, \mathrm{~N} 9$, and $\mathrm{M} 1$ from the Influenza A/Taiwan/1/2013 (H7N9) strain) of VLPs. The production yield of H7N9-TW VLPs using two different insect cell lines, Sf-21 cells and High Five ${ }^{\mathrm{ma}}$ cells, was compared, and the advantages of the newly developed process development strategy were combined with those of these two insect cell lines. First, we prepared the virus stock using Sf-21 cells based on their notably high viruspropagation ability and then infected High Five ${ }^{\text {tam }}$ cells for H7N9-TW VLP production. The culture conditions and the upstream process of VLP production were then optimized, and the scalability from a $500-\mathrm{mL}$ spinner flask to a 5-L bioreactor was also studied.

\section{Results and discussion}

\section{Establishment of the H7N9-TW VLP expression system}

The HA, NA, and M1 genes from the Influenza A/ Taiwan/1/2013 (H7N9) strain were cloned into the pFastBac DUAL vector (Invitrogen, USA) (Fig. 1). The resultant plasmid (H7N9-TW VLP) was employed to generate the recombination baculovirus for influenza VLP expression using the Bac-to-Bac ${ }^{\circ}$ system (Invitrogen) [11]. The recombination baculovirus was successfully established in a BEVS. To identify suitable cell lines for H7N9-TW VLP production, the cell growth ability of Sf-21 and High Five ${ }^{\text {Tx }}$ cells was compared. The Sf-21 cells were cultured in Sf- $900^{\text {max }}$ II SFM with an initial seeding cell density of $2 \times 10^{5}$ cells $/ \mathrm{mL}$, and their cell density reached $1.48 \times 10^{6}$ cells $/ \mathrm{mL}$ after 3 days (corresponding to a cell doubling time of $33.32 \mathrm{~h}$ ). In addition, the High Five ${ }^{\text {Ta }}$ cells were cultured in Express Five ${ }^{\circ}$ SFM with an initial seeding cell density of $2 \times 10^{5}$ cells $/ \mathrm{mL}$, and their cell density reached $3.30 \times 10^{6}$ cells $/ \mathrm{mL}$ after 3 days (corresponding to a cell doubling time of $18.30 \mathrm{~h}$ ) (Table 1). These data showed that High Five ${ }^{\mathrm{Tm}}$ cells exhibit improved growth than Sf-21 cells. In addition, the baculovirus titer generated with the Sf- 21 cells $\left(1 \times 10^{8}\right.$ virions $/ \mathrm{mL}$ ) was higher than that generated with the High Five ${ }^{\text {tu }}$ cells $\left(3 \times 10^{6}\right.$ virions $\left./ \mathrm{mL}\right)$ (Table 1$)$. These data showed that the Sf-21 cells exhibited higher baculovirus-production ability than the High Five ${ }^{\text {tm }}$ cells. The HA titers of H7N9-TW VLPs generated using these two cell lines were compared. The HA titer of the H7N9-TW VLPs produced using Sf-21 cells did not exceed 64 (HA units (HAU)/50 $\mu \mathrm{L}$ ), whereas the High Five $^{\text {Tw }}$ cells produced H7N9-TW VLPs with an HA titer of $512(\mathrm{HAU} / 50 \mu \mathrm{L})$ (Table 2), which demonstrated that H7N9-TW VLPs are more easily produced by High Five $^{\mathrm{Tm}}$ rather than Sf-21 cells. Previous studies revealed that the transfection of different insect cell lines with the same plasmid might result in various levels of protein expression and glycosylation [9, 34]. Therefore, High Five $^{\text {rm }}$ cells were selected as a host cell candidate for the production of influenza H7N9-TW VLPs using the BEVS system. Based on the above-described data, the best strategy for the development of this process comprised baculovirus replication in the Sf- 21 cells and 


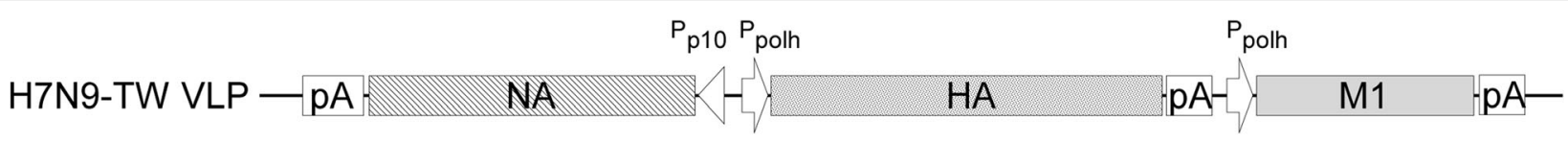

Fig. 1 Production of influenza H7N9-TW VLPs in the baculovirus expression vector system. CDNAs of the HA, NA, and M1 proteins were derived from the sequences of the Influenza A/Taiwan/1/2013 (H7N9) virus strain by polymerase chain reaction (PCR). The amplified DNA fragments were subcloned into the corresponding sites in a baculovirus expression vector

H7N9-TW VLP production in the High Five ${ }^{\mathrm{Tm}}$ cells. This two-step strategy was not only beneficial for baculovirus and H7N9-TW VLP production but also decreased baculovirus contamination, which simplified downstream purification (Fig. 2 and Additional file 1: Table S1).

\section{Protein composition and functional analysis of influenza H7N9-TW VLP}

The protein composition of H7N9-TW VLPs derived from High Five ${ }^{\mathrm{TM}}$ cells was analyzed by SDS-PAGE and western blotting. The levels of HA $(58 \mathrm{kDa}), \mathrm{NA}(48$ $\mathrm{kDa})$, and M1 (24 kDa) proteins were measured (Fig. 3a), and the composition of H7N9-TW VLPs was similar to that obtained in a previous study [35]. In addition, the HA and M1 proteins in H7N9-TW VLPs were recognized by the ferret anti-H7N9 antiserum generated in our previous study [36] (Fig. 3b). The neuraminidase activity of the NA protein was analyzed, and the results showed that the enzymatic activity of the NA protein was approximately $17 \mathrm{U}$ (nmol/hour/mL). These protein analyses indicated that the H7N9-TW VLP plasmid can be used to successfully express HA, NA and M1 proteins in a BEVS.

\section{Establishment of influenza H7N9-TW VLP production conditions}

With respect to upstream process development, serumfree media are essential for VLP production. The productivity levels of H7N9-TW VLPs derived from High

Table 1 Characteristics of Sf-21 and High Five ${ }^{\mathrm{TM}}$ cell growth and baculovirus virus and H7N9 TW-VLP production in a 300-mL shake flask

\begin{tabular}{|c|c|c|}
\hline Cell line & Sf-21 cell & High Five $^{T M}$ cell \\
\hline Medium & Sf- $900^{T M} \|$ SFM & Express Five ${ }^{\oplus}$ SFM \\
\hline Seeding cell density (cells/mL) & $2.0 \times 10^{5}$ & $2.0 \times 10^{5}$ \\
\hline Cell doubling time (hour) ${ }^{a}$ & 33.3 & 18.3 \\
\hline Harvested cell density (cells/mL) & $1.5 \times 10^{6}$ & $3.3 \times 10^{6}$ \\
\hline Fold increase of cell density & 7.4 & 15.3 \\
\hline Baculovirus virus $(\text { virion } / \mathrm{mL})^{b}$ & $1.0 \times 10^{8}$ & $3.1 \times 10^{6}$ \\
\hline HA titer (HAU/50 $\mu \mathrm{L})$ & 64 & 512 \\
\hline
\end{tabular}

${ }^{a}$ The cell doubling time was calculated using the following formula: DT = time (T) $x \ln 2 / \ln (X e / X b)$, where $T$ is the incubation time in any units, $X b$ is the cell number at the beginning of the incubation period, and $\mathrm{Xe}$ is the cell number at the end of the incubation period

${ }^{\mathrm{b}}$ The baculovirus titer (virion $/ \mathrm{mL}$ ) was calculated using the $\mathrm{TCID}_{50}$ method
Five $^{\mathrm{Th}}$ cells cultured with different media (HyClone $^{\mathrm{Tx}}$ SFM4Insect, EX-CELL ${ }^{\circ}$ 405, Esf-921, and Express Five SFM) in $300-\mathrm{mL}$ shake flasks were analyzed, and the results showed that the best HA titers in H7N9-TW VLPs generated with High Five ${ }^{\mathrm{rm}}$ cells were obtained by culturing in HyClone ${ }^{\mathrm{Tm}}$ SFM4Insect medium (Table 2). Specifically, the average HA titer was $256 \mathrm{HAU} / 50 \mu \mathrm{L}$. These data also showed that the nutrient composition of the medium affects the H7N9 influenza VLP levels, and the data were in good agreement with those obtained in previous studies [17]. Thus, in the subsequent experiments, the H7N9-TW VLPs were generated using High Five ${ }^{\text {tx }}$ cells in HyClone medium. According to a previous study [14], the MOI is a critical factor in VLP production. Hence, the effect of the MOI on the production of the H7N9-TW VLPs using High Five ${ }^{\mathrm{m}}$ cells cultured in HyClone $^{\text {tx }}$ SFM4Insect medium was monitored. In this study, High Five ${ }^{\mathrm{Tx}}$ cells at a cell density of $2.00 \times 10^{6}$ cells $/ \mathrm{mL}$ were infected with baculovirus at an MOI of 0.1 and 1.0. The HA titer of the VLPs generated from an MOI of 0.1 did not exceed $32(\mathrm{HAU} / 50 \mu \mathrm{L})$ in all tested media, and the HA titer obtained with an MOI of 1 reached approximately $256(\mathrm{HAU} / 50 \mu \mathrm{L})$. Thus, the data suggested that a high MOI could enhance the production of H7N9-TW VLPs in the BEVS (Fig. 4).

\section{Optimization of H7N9-TW VLP production conditions}

For scale-up, efficiency and controllable production are crucial issues. The shaker flask is limited by a low working volume-to-flask volume ratio. Specifically, the use of a shaker flask requires more space for culture, and the transfer of culture conditions from shake flasks to benchtop bioreactors is challenging. However, the spinner flask system is usually considered for use in pilot studies aiming to scale-up production to a benchtop bioreactor because the culture conditions used in these two systems are highly similar [37, 38]. Therefore, the culture systems in shake and spinner flasks for H7N9- TW VLP production were compared. The total cell number of both systems increased from $2 \times 10^{5}$ cells $/ \mathrm{mL}$ to $2 \times 10^{6}$ cells/mL during 3 days of culture. The metabolic parameters, including the total cell number, glucose consumption, and $\mathrm{pH}$ were similar between these two systems (Fig. 5). Surprisingly, a considerable difference in the DO level was observed (Fig. 6a). The DO level in the 500-mL spinner flask during the production period decreased 
Table 2 Comparison of High Five ${ }^{\mathrm{TM}}$ cells cultured in 300-mL shake flasks with different commercially available culture media

\begin{tabular}{llllll}
\hline $\begin{array}{l}\text { Name of commercial } \\
\text { medium }\end{array}$ & $\begin{array}{l}\text { Seeding cell density } \\
(\text { cells/mL) }\end{array}$ & $\begin{array}{l}\text { Harvested cell density } \\
\text { (cells/mL) }\end{array}$ & $\begin{array}{l}\text { Cell doubling time } \\
\text { (hour) }\end{array}$ & $\begin{array}{l}\text { Fold increase of cell } \\
\text { density }\end{array}$ & $\begin{array}{l}\text { HA titer (HAU/ } \\
50 \mu L)\end{array}$ \\
\hline HyClone ${ }^{\text {TM }}$ SFM4Insect & $2.00 \times 10^{5}$ & $2.60 \times 10^{6}$ & 19.46 & 13.00 & 512 \\
EX-CELL ${ }^{\oplus} 405$ & $2.00 \times 10^{5}$ & $1.80 \times 10^{6}$ & 22.71 & 9.00 & 256 \\
Esf-921 & $2.05 \times 10^{5}$ & $2.25 \times 10^{6}$ & 20.83 & 10.98 & 256 \\
Express Five ${ }^{\oplus}$ SFM & $2.16 \times 10^{5}$ & $3.30 \times 10^{6}$ & 18.30 & 15.28 & 256 \\
\hline
\end{tabular}

from 150 to $30 \mathrm{mmHg}$, whereas a DO level of approximately 100 to $150 \mathrm{mmHg}$ was detected in the $300-\mathrm{mL}$ shaker flasks during the production period. This could result from the lower gas-liquid oxygen transfer in the gentle-mixing spinner-flask whereas the shake flask has higher gas-liquid oxygen transfer by higher agitation speed. To confirm this phenomenon, the experiment was performed in 500-mL spinner flasks with a small air pump that continuously filtered-air supply to the headspace (ventilated spinner flask). The DO levels in this system were similar to those in the shake flask system (Fig. 6a). Additionally, analysis of the H7N9-TW VLP yield showed that an HA titer of $512 \mathrm{HAU} /$ $50 \mu \mathrm{L}$ was obtained with this system, and a similar titer was obtained with the 300-mL shake flask (Fig. 6b). In contrast, analysis of the yield of H7N9-TW VLPs obtained with the 500-mL spinner flask showed that the HA titer ranged from only 2 to $4 \mathrm{HAU} / 50 \mu \mathrm{L}$. The results showed that the DO

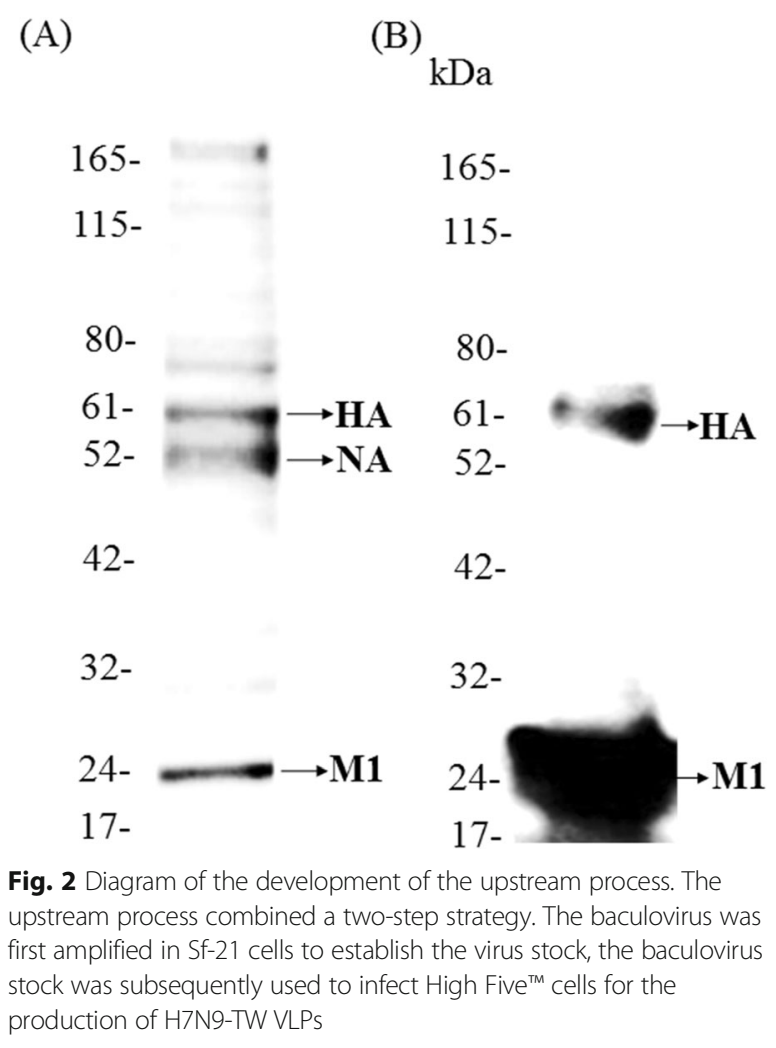

level played a critical role in the production of H7N9-TW VLPs. Previous studies revealed that the DO level in insect cells could affect both the protein expression levels [39] and the production of foreign protein by insect cells [40]. These studies provide possible reasons explaining why H7N9-TW VLP production was affected by the DO level in this study.

\section{Evaluation of the scale-up feasibility of the process}

According to the culture parameters found for High Five ${ }^{\mathrm{TM}}$ cells in 500-mL ventilated spinner flasks, the High Five ${ }^{\text {тм }}$ cells were inoculated at a cell density of $2 \times 10^{5}$ cells $/ \mathrm{mL}$ and cultured in a 5-L bioreactor system with HyClone ${ }^{\text {тM }}$ SFM4Insect medium. The cell density in this bioreactor system reached $2.42 \times 10^{6}$ cells $/ \mathrm{mL}$ after 3 days, and the cell growth profile was similar to that obtained with the $500-\mathrm{mL}$ ventilated spinner flask (Fig. 7a). High Five ${ }^{\mathrm{Tm}}$ cells were infected with baculovirus at an MOI of 1 in the 5-L bioreactor, and the viability of the High Five ${ }^{\mathrm{TM}}$ cells declined by 20 to $30 \%$ during the infection (Fig. 7a). The culture conditions for High Five ${ }^{\mathrm{Tm}}$ cells in this 5-L bioreactor system, including the $\mathrm{pH}$, glucose consumption, and DO, were also evaluated. During the culture period, the $\mathrm{pH}$ was maintained at 6.4; the initial glucose concentration decreased from an initial concentration of approximately $10.0 \mathrm{~g} / \mathrm{L}$ to approximately $50 \%$ (from $10.0 \mathrm{~g} / \mathrm{L}$ to $5.0 \mathrm{~g} / \mathrm{L}$ ) (Fig. 7c); and the DO was maintained at approximately $80 \%$ (equivalent to 150 $\mathrm{mmHg}$ ). For H7N9-TW VLP production, High Five ${ }^{\mathrm{Tm}}$ cells were harvested on day 3, and the HA titer of VLPs was 512 $\mathrm{HAU} / 50 \mu \mathrm{L}$ (Fig. 7b), which was similar to that obtained from VLPs produced at the pilot scale $(500 \mathrm{~mL})$. These results demonstrated that H7N9-TW VLP production can be scaled up to a 5 -L bioreactor system and that this process exhibits good linear scalability Additional file 2: Table S2.

Furthermore, the level of DO, which is the critical parameter for H7N9-TW VLP production, in the 5-L bioreactor was maintained at $30 \%$ (equivalent to $50 \mathrm{mmHg}$ ) or $80 \%$ (equivalent to $150 \mathrm{mmHg}$ ) (Table 3 , groups 1 and 3), and the growth profiles of the cells did not show differences between these two conditions. However, the HA titer was substantially improved by 128 -fold in the $80 \%$ DO group compared with the $30 \%$ DO group. In addition, we also used a high cell density (approximately $8 \times 10^{6}$ cells $/ \mathrm{mL}$ ) and a low level of DO (30\%) for H7N9TW VLP production in the 5-L bioreactor and obtained an HA titer of H7N9-TW VLPs that was less than 2 


\section{Step 1 . Amplification of baculovirus :}

\begin{tabular}{|c|c|c|c|}
\hline & & (High virus titer) & (low VLP production) \\
\hline & Infected baculovirus stock & Baculovirus & $17 \mathrm{Na}$ \\
\hline
\end{tabular}

\section{Step 2. The H7N9-TW VLP production:}

Fig. 3 Analysis of H7N9-TW VLP expression by a SDS-PAGE and $\mathbf{b}$ western blotting. High Five ${ }^{\text {TM }}$ cells were infected with the baculovirus, and at 3 days postinfection, the resulting H7N9-TW VLPs were harvested and analyzed

HAU $/ 50 \mu \mathrm{L}$ (Table 3, group 2). These data meet our expectations, which indicated that the DO level is indeed a critical factor affecting the VLP production yield in the upstream process and showed that the maintenance of a DO level of approximately $150 \mathrm{mmHg}$ could enhance H7N9-TW VLP production. This VLP vaccine production platform not only determines the critical factors for enhancing the product yield but also reduces the biosafety concerns related to the manufacturing of vaccines $[3,41]$.

\section{Conclusions}

An H7N9-TW VLP expression platform using a BEVS was established, and the culture conditions were improved to obtain higher HA titers. This strategy involves

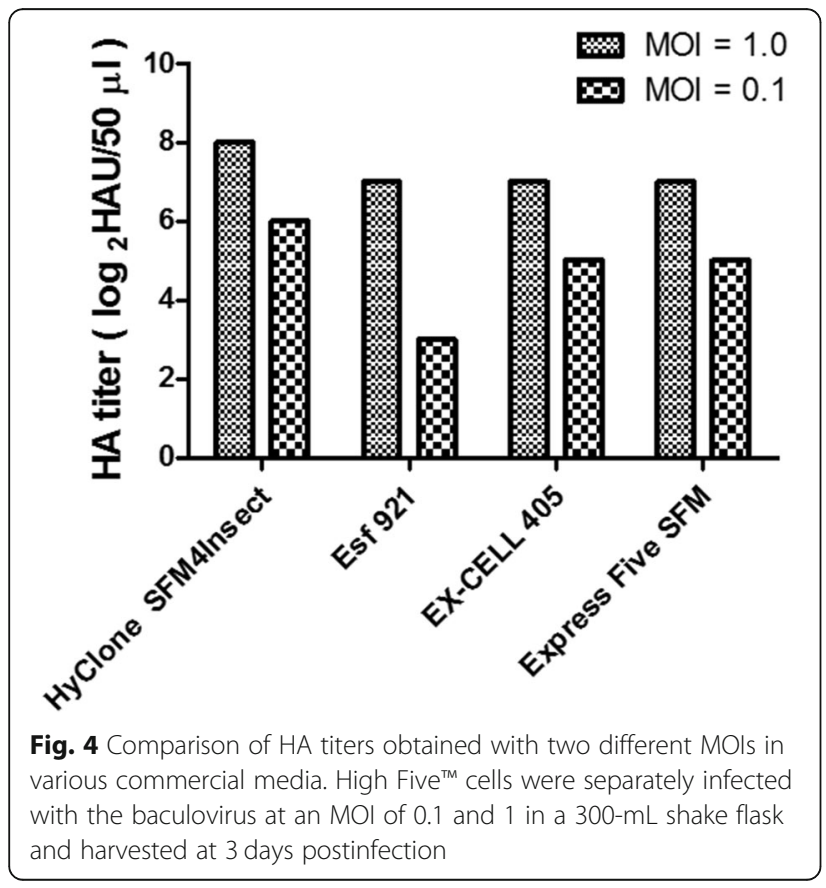

the use of two insect cell lines, Sf-21 and High Five ${ }^{\mathrm{m}}$ cells, and exhibits excellent performance for H7N9-TW VLP production, and the results of this study also demonstrate the optimal conditions for more rapid and efficient influenza VLP vaccine manufacturing. This study not only revealed improvements to not only the upstream process conditions but also found the critical parameter for enhancing the H7N9-TW VLP production yield. The improved upstream process for VLP vaccine production, which involves a two-step strategy, a high MOI, and a well-controlled level of dissolved oxygen, was successfully scaled up to a bioreactor system, and thus, the newly developed process could be easily scaled up to an industrial level in the future.

\section{Methods}

Cell culture and media

Sf-21 cells (Invitrogen, USA) were cultured in Sf-900II serum-free medium (Gibco, USA) for baculovirus production. For H7N9-TW VLP production, High Five ${ }^{\mathrm{Th}}$ cells (Invitrogen, USA) were cultured in various serum-free,

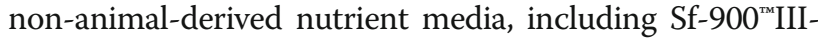
SFM (Gibco, USA), HyClone ${ }^{\text {tx }}$ SFM4Insect medium (GE Healthcare, USA), Insect-XPRESS ${ }^{\mathrm{m}}$ medium (Lonza, Switzerland), and Express Five ${ }^{\circ}$ SFM (Gibco, USA) supplemented with $9 \mathrm{mML}$-glutamine. These insect cell lines were cultured at $27^{\circ} \mathrm{C}$.

\section{Preparation of recombinant baculoviruses}

The pFastBac-p10-2polh promoter included one p10 promoter and two polh promoters bidirectionally, and each promoter had a polyadenylation [poly(A)] signal. The gene fragment of the second polh promoter and sv40 poly(A) were amplified from the pFastBac DUAL vector (Invitrogen, USA) by polymerase chain reaction (PCR) and cloned into the NotI/AvrII sites of the pFastBac DUAL vector to generate pFastBac-p10-2polh. The NA, HA, and M1 gene 


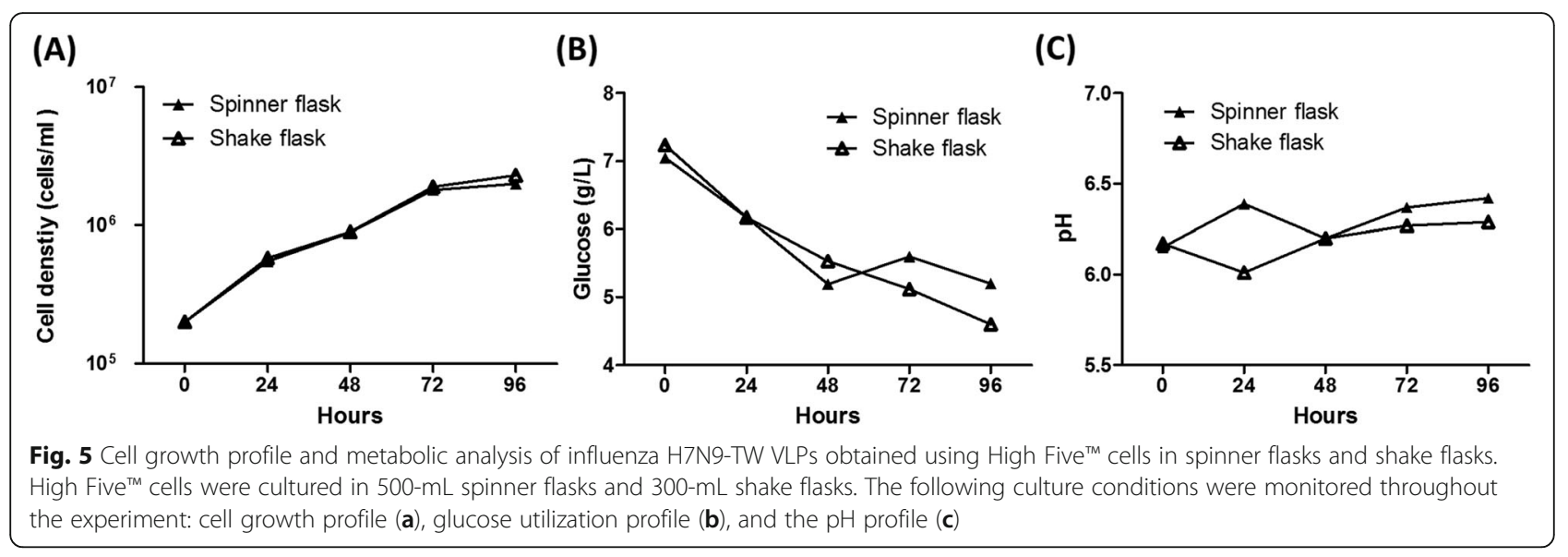

fragments were obtained by PCR from cDNA isolated from the Influenza A/Taiwan/1/2013 (H7N9) strain and cloned into the KpnI site under the control of the p10 promoter, the RsrII site under the control of the first polh promoter, and the XbaI site under the control of the second polh promoter in pFastBac-p10-2polh, respectively, to generate $\mathrm{pH} 7 \mathrm{N9}$-TW VLPs. The resulting plasmid was employed to generate H7N9-TW VLPs using the Bac-to$\mathrm{Bac}^{\circ}$ system (Invitrogen, USA) [11]. The baculoviruses were propagated by infecting Sf-21 cells (Invitrogen, USA) cultured in Grace's insect basal medium (Invitrogen, USA) supplemented with 10\% FBS (Gibco, USA) and harvested for H7N9-TW VLP production.

\section{Shake and spinner flask cultures of high five ${ }^{\mathrm{TM}}$ cells}

The cultures were performed in 1-L shake flasks with a working volume of $300 \mathrm{~mL}$. Each flask was inoculated with the cells at a density of approximately $2 \times 10^{5}$ cells/ $\mathrm{mL}$. Once the High Five ${ }^{\mathrm{rm}}$ cell density reached $2 \times 10^{6}$ cells $/ \mathrm{mL}$, the cells were separately infected at MOI values of 0.1 and 1 . The H7N9-TW VLPs were harvested
3 days postinfection (dpi) by low-speed centrifugation at $4000 \mathrm{x} \mathrm{g}$ and $4{ }^{\circ} \mathrm{C}$ for $30 \mathrm{~min}$, and the H7N9-TW VLP yield was then determined through an HA assay. Additionally, the cultures were performed in 1-L spinner flasks with a working volume of $500 \mathrm{~mL}$ and the same initial cell density and infection time that were used for the shake flask cultures. The cells were infected with the baculovirus at an MOI of 1 , and the culture temperature during the upstream process were maintained at $28^{\circ} \mathrm{C}$. In addition, the level of DO was monitored during the process, and the H7N9-TW VLP production level was determined by HA titration.

\section{SDS-PAGE and western blot analysis}

Approximately $1 \mu \mathrm{g}$ of total protein from purified H7N9TW VLPs was separated by $10 \%$ SDS-PAGE gels and stained using a Colloidal Blue staining kit (Invitrogen, USA). A western blot analysis was also performed as described previously [42]. The SDS-PAGE gel was electroblotted to a PVDF membrane, and this membrane was then blocked overnight with 5\% nonfat milk and
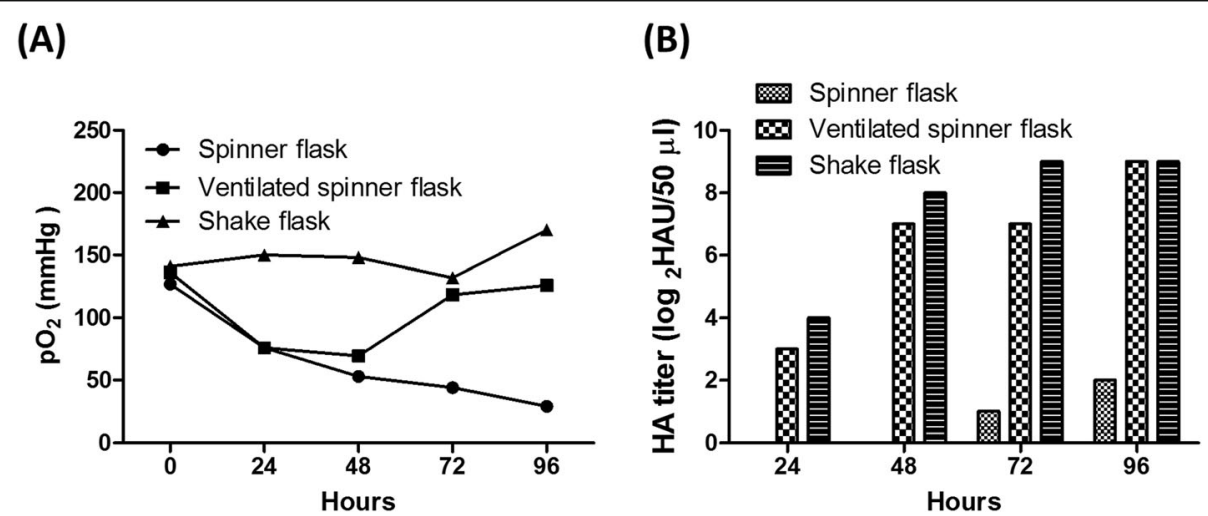

Fig. 6 Influence of dissolved oxygen on H7N9-TW VLP production. High Five ${ }^{\text {TM }}$ cells were cultured in 500-mL spinner flasks, spinner flasks, and shake flasks with air ventilation $(100 \mathrm{~mL} / \mathrm{min}$ ) and infected with baculovirus. The DO concentration profile (a) and H7N9-TW VLP production profile (b) were monitored during the upstream process 

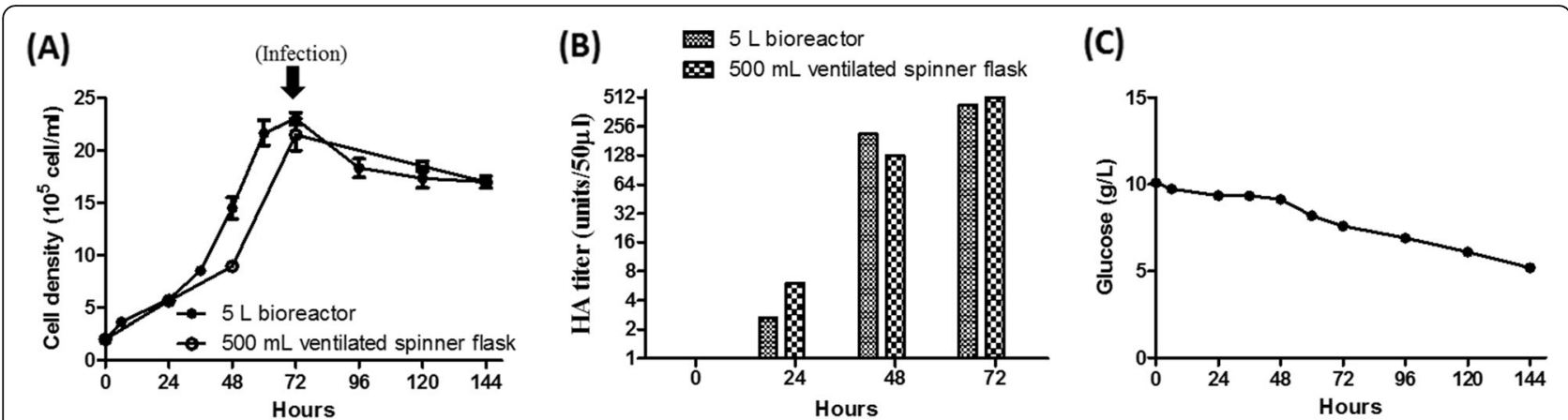

Fig. 7 Comparison of the scalability of the upstream process from a $500-\mathrm{mL}$ ventilated spinner flask to the 5 -L bioreactor system. High Five ${ }^{\mathrm{TM}}$ cells were cultured in a 500-mL ventilated spinner flask and a 5-L bioreactor system, and the DO concentration was maintained at $80 \%$ throughout the production period. Once the Sf-21 cell density reached $2 \times 10^{6}$ cells $/ \mathrm{mL}$, the cells were infected with the baculovirus. The cell growth curve (a), the H7N9-TW VLP production profile (b), and the glucose utilization profile (c) were monitored during the upstream process

incubated with ferret anti-H7N9 antibody [36] (1:1000) in PBS with $0.1 \%$ Tween 20 (PBST) for $1 \mathrm{~h}$ at room temperature (RT). The membrane was then incubated with goat anti-ferret IgG (HRP) (1:10,000, Abcam, USA) in PBST for $1 \mathrm{~h}$ at RT. The blots were developed using the Luminata $^{\mathrm{Tm}}$ Crescendo Western HRP substrate (Millipore, USA), and images were captured using the Amersham Imager 600 system (GE Healthcare, USA).

\section{Assay of NA activity}

The NA activity assay as performed using the NAFluor $^{\mathrm{Tm}}$ Influenza Neuraminidase assay protocol (Applied Biosystems, USA). The H7N9-TW VLPs were mixed with 2-(4-methylumbelliferyl)-a- $\mathrm{D}-\mathrm{N}$-acetylneuraminic acid to a final concentration of $100 \mu \mathrm{M}$ and incubated at $37^{\circ} \mathrm{C}$ on a shaker for $40 \mathrm{~min}$, and the reaction was stopped by the addition of stop solution. Fluorometric measurements were performed immediately using a SpectraMAX M2 Reader with an excitation wavelength of $365 \mathrm{~nm}$ and an emission wavelength of $450 \mathrm{~nm}$ [43].

\section{Virological assays}

HA titration was conducted in 96-well microplates using $0.5 \%$ turkey red blood cells following standard protocols

Table 3 Comparison of H7N9-TW VLP production in a 5-L bioreactor with different control parameters

\begin{tabular}{llll}
\hline Parameter/Group & 1 & 2 & 3 \\
\hline Cell density $\left(10^{6} \text { cells } / \mathrm{mL}\right)^{\mathrm{a}}$ & 2.0 & 8.0 & 2.4 \\
$\mathrm{DO}(\%)$ & 30 & 30 & 80 \\
$\mathrm{pH}$ & 6.4 & 6.4 & 6.4 \\
Agitation rate $(\mathrm{rpm})^{\mathrm{b}}$ & $120-180$ & $120-180$ & $120-180$ \\
$\mathrm{HA}$ titer $(\mathrm{HAU} / 50 \mu \mathrm{L})$ & 8 & $<2$ & 512 \\
\hline
\end{tabular}

High Five ${ }^{\mathrm{TM}}$ cells were cultured in a 5-L bioreactor with different control parameters, infected with the baculovirus and harvested at 3 days postinfection

${ }^{a}$ The cell density value indicates the cell density at which baculovirus infection was performed

${ }^{\mathrm{b}}$ The agitation rate was adjusted depending on the cell density during culture
[44]. The virus infectious titers were measured by assaying the $50 \%$ tissue culture infectious dose $\left(\mathrm{TCID}_{50}\right)$ based on the cytopathic effect in Sf-21 cells [45].

\section{Production of H7N9-TW VLPs in the bioreactor}

A 5-L bioreactor (NBS, USA) was used based on the same principles as the $500-\mathrm{mL}$ ventilated spinner flask. The culture conditions were set using a BioFlo 310 controller (NBS, USA). Throughout the culture period, the culture was mixed with a three-pitch blade impeller at 120 to $180 \mathrm{rpm}$, the $\mathrm{pH}$ value was maintained at 6.4 , and the temperature was maintained at $28^{\circ} \mathrm{C}$. Once the desired cell concentration was reached, High Five ${ }^{\mathrm{Tm}}$ cells were infected with the recombination baculovirus at an MOI of 1 , and the cells were harvested when the hematogluttin HA titer peaked. During the culture period, the HA titer, which was considered to reflect the level of H7N9-TW VLP production, was monitored, and the concentration of glucose in the culture supernatant was measured offline using a NOVA BioProfile 400 biochemical analyzer (Nova Biomedical Corporation, USA).

\section{Supplementary information}

Supplementary information accompanies this paper at https://doi.org/10. 1186/s13036-019-0206-z.

Additional file 1: Table S1. Comparison of influenza VLP production by different insect cells.

Additional file 2: Table S2. Comparison of influenza VLPs production with shake flask and Bioreactor.

\section{Abbreviations}

BEVS: Baculovirus expression vector system; DO: Dissolved oxygen; HA titer: Hemagglutinin titer; MOI: Multiplicity of infection; PBST: PBS with $0.1 \%$ Tween 20; TCID 50 : 50\% tissue culture infectious dose; ventilated spinner flask: Spinner flask with a small air pump that continuously supplied air to the headspace; VLP: Virus-like particle 


\section{Acknowledgements}

Mr. Chia-Chun Lai conducted his thesis research under the auspices of the Graduate Program of Biotechnology in Medicine at the National Tsing Hua University and National Health Research Institutes.

\section{Authors' contributions}

AYCH conceived the concept of the review. CCL was the primary author, with contributions from PWC, THL, TT, and CCL. MSL and YCC edited and revised the manuscript. All authors read and approved the final manuscript.

\section{Funding}

The authors would like to thank the funding support provided by the Ministry of Science and Technology (Grant Nos. 106-2321-B-400-010 and 107-2321-B-400-007.

\section{Availability of data and materials}

Not applicable.

Ethics approval and consent to participate

Not applicable.

\section{Consent for publication}

Not applicable.

\section{Competing interests}

The authors declare that they have no competing interests.

\section{Author details}

${ }^{1}$ National Institute of Infectious Diseases and Vaccinology, NHRI, 35 Keyan Road, Zhunan, Miaoli County 35053, Taiwan. ${ }^{2}$ College of Life Science, National Tsing Hua University, 101, Section 2, Kuang-Fu Road, Hsinchu 30013, Taiwan.

Received: 17 June 2019 Accepted: 6 September 2019

Published online: 23 October 2019

\section{References}

1. Grohskopf LA SL, Broder KR, Walter EB, Fry AM, Jernigan DB.: Prevention and Control of Seasonal Influenza with Vaccines: Recommendations of the Advisory Committee on Immunization Practices-United States, 2018-19 Influenza Season. 2018 67(3):1-20.

2. Lua LH, Connors NK, Sainsbury F, Chuan YP, Wibowo N, Middelberg AP. Bioengineering virus-like particles as vaccines. Biotechnol Bioeng. 2014;111: 425-40.

3. Roldao A, Mellado MC, Castilho LR, Carrondo MJ, Alves PM. Virus-like particles in vaccine development. Expert Rev Vaccines. 2010;9:1149-76.

4. Frietze KM, Peabody DS, Chackerian B. Engineering virus-like particles as vaccine platforms. Curr Opin Virol. 2016:18:44-9.

5. Liu F, Wu X, Li L, Liu Z, Wang Z. Use of baculovirus expression system for generation of virus-like particles: successes and challenges. Protein Expr Purif. 2013;90:104-16.

6. Thompson CM, Aucoin MG, Kamen AA. Production of virus-like particles for vaccination. Methods Mol Biol. 2016:1350:299-315.

7. Effio $\mathrm{CL}$, Hubbuch J. Next generation vaccines and vectors: designing downstream processes for recombinant protein-based virus-like particles. Biotechnol J. 2015;10:715-27.

8. Huang $X$, Wang $X$, Zhang J, Xia N, Zhao Q. Escherichia coli-derived virus-like particles in vaccine development. NPJ Vaccines. 2017;2:3.

9. Fuenmayor J, Godia F, Cervera L. Production of virus-like particles for vaccines. New Biotechnol. 2017;39:174-80.

10. Yamaji H, Konishi E. Production of Japanese encephalitis virus-like particles in insect cells. Bioengineered. 2013;4:438-42.

11. Guide to Baculovirus Expression Vector Systems (BEVS) and Insect Cell Culture Techniques. Instruction Manual 2002.

12. Wickham TJDT, Granados RR, Shuler ML, Wood HA. Screening of insect cell lines for the production of recombinant proteins and infectious virus in the Baculovirus expression system. Biotechnol Prog. 1992;8:391-6.

13. Corporation LT (Ed.). Growth and maintenance of insect cell lines User Guide Revision A.0: Instruction Manual. ; 2017.

14. Zhang YH, Enden G, Merchuk JC. Insect cells-Baculovirus system: factors affecting growth and low MOI infection. Biochem Eng J. 2005;27:8-16.
15. Thompson CM, Petiot E, Mullick A, Aucoin MG, Henry O, Kamen AA. Critical assessment of influenza VLP production in Sf9 and HEK293 expression systems. BMC Biotechnol. 2015;15:31.

16. Lopez-Vidal J, Gómez-Sebastián S, Barcena J, Nunez Mdel C, MartinezAlonso D, Dudognon B, Guijarro E, Escribano JM. Improved production efficiency of virus-like particles by the Baculovirus expression vector system. PLoS One. 2015;10:e0140039.

17. Krammer F, Schinko T, Palmberger D, Tauer C, Messner P, Grabherr R. Trichoplusia ni cells (high five) are highly efficient for the production of influenza a virus-like particles: a comparison of two insect cell lines as production platforms for influenza vaccines. Mol Biotechnol. 2010;45:226-34

18. Ignacio Casal J. Use of the Baculovirus expression system for the generation of virus-like particles. Biotechnol Genet Eng Rev. 2001;18:73-87.

19. Chung CY, Chen CY, Lin SY, Chung YC, Chiu HY, Chi WK, Lin YL, Chiang BL, Chen WJ, Hu YC. Enterovirus 71 virus-like particle vaccine: improved production conditions for enhanced yield. Vaccine. 2010;28:6951-7.

20. Bornstein J. The HPV vaccine market: Cervarix ${ }^{{ }^{T M}}$ competes with Gardasil ${ }^{\circledR}$. Therapy. 2010;7(1):75.

21. Wang JW, Roden RB. Virus-like particles for the prevention of human papillomavirus-associated malignancies. Expert Rev Vaccines. 2013;12:129-41.

22. Li X, Pushko P, Tretyakova I. Recombinant hemagglutinin and virus-like particle vaccines for H7N9 influenza virus. J Vaccines Vaccin. 2015;6.

23. Dai S, Zhang Y, Zhang T, Zhang B, Wang H, Deng F. Establishment of Baculovirus-expressed VLPs induced syncytial formation assay for Flavivirus antiviral screening. Viruses. 2018;10.

24. Mohsen MO, Zha L, Cabral-Miranda G, Bachmann MF. Major findings and recent advances in virus-like particle (VLP)-based vaccines. Semin Immunol. 2017:34:123-32

25. Liu YV, Massare MJ, Pearce MB, Sun X, Belser JA, Maines TR, Creager HM, Glenn GM, Pushko P, Smith GE, Tumpey TM. Recombinant virus-like particles elicit protective immunity against avian influenza a(H7N9) virus infection in ferrets. Vaccine. 2015:33:2152-8.

26. Kushnir N, Streatfield SJ, Yusibov V. Virus-like particles as a highly efficient vaccine platform: diversity of targets and production systems and advances in clinical development. Vaccine. 2012;31:58-83.

27. Novavax' H7N9 avian influenza VLP vaccine positive in Phase 1/2. Hum Vaccin Immunother. 2014;10:3103.

28. Pushko P, Kort T, Nathan M, Pearce MB, Smith G, Tumpey TM. Recombinant H1N1 virus-like particle vaccine elicits protective immunity in ferrets against the 2009 pandemic H1N1 influenza virus. Vaccine. 2010;28:4771-6.

29. Bright RA, Carter DM, Daniluk S, Toapanta FR, Ahmad A, Gavrilov V, Massare M, Pushko P, Mytle N, Rowe T, et al. Influenza virus-like particles elicit broader immune responses than whole virion inactivated influenza virus or recombinant hemagglutinin. Vaccine. 2007;25:3871-8.

30. Cox MM, Patriarca PA, Treanor J. FluBlok, a recombinant hemagglutinin influenza vaccine. Influenza Other Respir Viruses. 2008;2:211-9.

31. Cox MMIR, Post P, Dunkle L. Safety, efficacy, and immunogenicity of Flublok in the prevention of seasonal influenza in adults. Ther Adv Vaccines. 2015; 3(4):97-108.

32. Chang S-Y, Lin P-H, Tsai J-C, Hung C-C, Chang S-C. The first case of H7N9 influenza in Taiwan. Lancet. 2013;381:1621.

33. Yang JR, Kuo CY, Huang HY, Wu FT, Huang YL, Cheng CY, Su YT, Wu HS, Liu MT. Characterization of influenza a (H7N9) viruses isolated from human cases imported into Taiwan. PLoS One. 2015;10:e0119792.

34. Wu CY, Yeh YC, Yang YC, Chou C, Liu MT, Wu HS, Chan JT, Hsiao PW. Mammalian expression of virus-like particles for advanced mimicry of authentic influenza virus. PLoS One. 2010;5:e9784.

35. Smith GE, Flyer DC, Raghunandan R, Liu Y, Wei Z, Wu Y, Kpamegan E, Courbron D, Fries LF 3rd, Glenn GM. Development of influenza H7N9 virus like particle (VLP) vaccine: homologous a/Anhui/1/2013 (H7N9) protection and heterologous a/chicken/Jalisco/CPA1/2012 (H7N3) cross-protection in vaccinated mice challenged with H7N9 virus. Vaccine. 2013;31:4305-13.

36. Chia MY, Hu AY, Tseng YF, Weng TC, Lai CC, Lin JY, Chen PL, Wang YF, Chao SR, Chang JY, et al. Evaluation of MDCK cell-derived influenza H7N9 vaccine candidates in ferrets. PLoS One. 2015;10:e0120793.

37. Fernandes-Platzgummer A, Diogo MM, Baptista RP, da Silva CL, Cabral JM. Scale-up of mouse embryonic stem cell expansion in stirred bioreactors. Biotechnol Prog. 2011;27:1421-32.

38. Hu AY, Tseng YF, Weng TC, Liao CC, Wu J, Chou AH, Chao HJ, Gu A, Chen J, $L$ in $\mathrm{SC}$, et al. Production of inactivated influenza $\mathrm{H} 5 \mathrm{~N} 1$ vaccines from MDCK cells in serum-free medium. PLoS One. 2011;6:e14578. 
39. Hidalgo D, Paz E, Palomares LA, Ramirez OT. Real-time imaging reveals unique heterogeneous population features in insect cell cultures. J Biotechnol. 2017:259:56-62

40. Zhang FSM, Itle LI, Lang SC, Murhammer DW, Linhardt RJ. The effect of dissolved oxygen (DO) concentration on the glycosylation of recombinant protein produced by the insect cell-baculovirus expression system. Biotechnol Bioeng. 2002;2002:219-24.

41. Quan FS, Lee YT, Kim KH, Kim MC, Kang SM. Progress in developing viruslike particle influenza vaccines. Expert Rev Vaccines. 2016;15:1281-93.

42. Li C, Xu K, Hashem A, Shao M, Liu S, Zou Y, Gao Q, Zhang Y, Yuan L, Xu M, et al. Collaborative studies on the development of national reference standards for potency determination of H7N9 influenza vaccine. Hum Vaccin Immunother. 2015;11:1351-6.

43. Leang SK, Hurt AC. Fluorescence-based neuraminidase inhibition assay to assess the susceptibility of influenza viruses to the neuraminidase inhibitor class of antivirals. J Vis Exp. 2017.

44. WHO. WHO manual on animal influenza diagnosis and surveillance. Geneva; 2002.

45. Genzel Y, Behrendt I, Rodig J, Rapp E, Kueppers C, Kochanek S, Schiedner G, Reichl U. CAP, a new human suspension cell line for influenza virus production. Appl Microbiol Biotechnol. 2013;97:111-22.

\section{Publisher's Note}

Springer Nature remains neutral with regard to jurisdictional claims in published maps and institutional affiliations.

Ready to submit your research? Choose BMC and benefit from:

- fast, convenient online submission

- thorough peer review by experienced researchers in your field

- rapid publication on acceptance

- support for research data, including large and complex data types

- gold Open Access which fosters wider collaboration and increased citations

- maximum visibility for your research: over $100 \mathrm{M}$ website views per year

At $\mathrm{BMC}$, research is always in progress.

Learn more biomedcentral.com/submissions 